\title{
2P2-C2 人工臟器の埋め込みシミュレーション
}

Computer simulation to determine the anatomical compatibility of implantable artificial organs

○小蓦宗史, 雨宮真一郎, 福長一義*, 福井康裕, 本間章彦**, 巽英介**, 妙中義之**, 北村忽一郎**

束京電機大学大学院理工学研究科 電子情報工学専攻,*フロンティア共同研究センター,

**国立循環器病センター研究所

Takashi Kogure, Shinichirou Amemiya, Kazuyoshi Fukunaga, Yasuhiro Fukui,

Akihiko Homma**, Eisuke Tatsumi**, Yoshiyuki Taenaka**, Souichirou Kitamura**

Graduate School of Electronic and Computer Engineering, Tokyo Denki University,

*Frontier Research and Development Center, **Research Institute of National Cardiovascular Center

\section{1. はじめに}

近年,バーチャルリアリティー技術を忘用した仮想空間に おける手術の計画支援や, 術前シミュレーションなどが行われ ている。

本研究では，人工心臓を合併症なく患者の限られた胸腔 内に埋め込むために，接触や圧迫による変形をコンピュータ 上で表現することが可能な埋め込みシミュレーション技術の 開発に取り組んでいる。

現在までに, CT 画像から構築した臟器の 3 次元イメージと, CAD ソフトにより作成した人工心臓の 3 次元イメージをコンピ ュータ上で合成表示することで, 手術方針の決定や人工心 臟形状検討のための埋め込みシミュレーションを行ってきた。 例として，国立循環器病センターで開発を行っている電気油 压駆動方式全人工心臟の埋め込みシミュレーション結果を Figure 1 に示す。

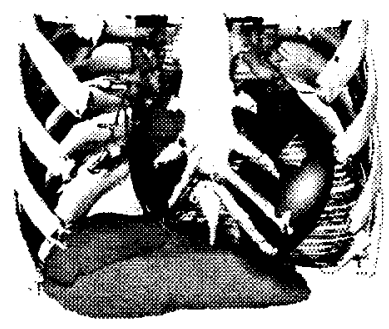

(a) Front view

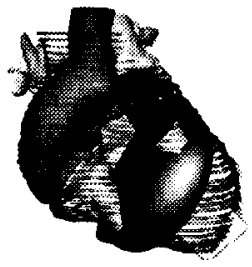

(b) Front View without breast bone
Figure 1. Simulation Result.

Figure 1 において，人工心臓が心裏内に収まっていない部 分や, 肝臓などの周辺臟器への接触や圧迫が確認できる。こ のような場合において人工心臟と周辺臟器との接触, 圧迫の 程度を定量的に評価することが必要である。

\section{2. 目的}

人工心贜と周辺組織との接触の判定, それに伴う変形, 応 力值を求め, リアルタイムでそれらを確認できる埋め込みシミ ユレーション技術の開発を目的とする。今回，臓器モデルの 変形, 応力值の算出を効率的に行うための弾性変形モデル について基礎的検討を行った。

\section{3. 弹性支形モデル}

生体組織をコンピュータ上に構筑するための基本モデルと して、バネ質点モデルを用いた。対象物体を微小要素に分割,
各頂点に質点を配置し, 物体の変形を全質点の挙動で模擬 する。このとき質点は(1)式の運動方程式に従う。このモデル は構造が単純なため,リアルタイム演算に向いている。

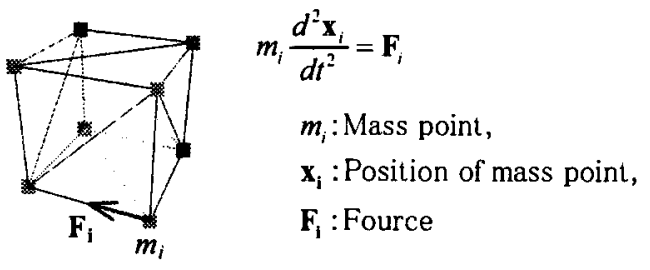

Figure 2. Spring-mass model.

\section{4. シミュレーション結果}

CT 画像より 3 次元構築した肝臟モデルと人工心臓パーツ を想定した剛性物体モデルを用いて，接触に伴う物体の変 形, 応力值を算出するシミュレーションを行った。肝臟の物性 值 "は, 密度 $1\left[\mathrm{~g} / \mathrm{cm}^{3}\right]$, 縦弹性係数 $2.7\left[\mathrm{~N} / \mathrm{cm}^{2}\right]$, ポアソン比 0.36 とした。

マウス操作により,一辺が $40[\mathrm{~mm}]$ の立方体の剛性物体モ デルを肝臓モデルに接触させるシミュレーションを行い, Figure 3 のように変形することを確認した。 (a) Before deformation

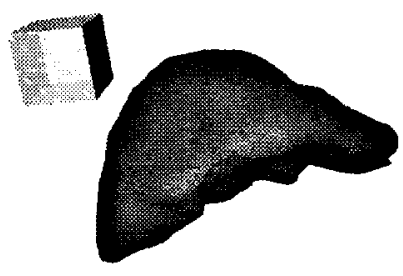

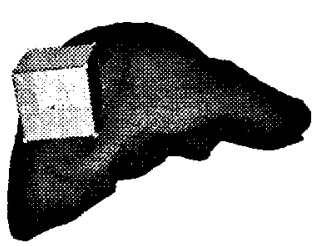

(b) After deformation
Figure 3. Simulation result of deformation.

Nodes of liver model : 1002, Elements of liver model: 2000 , Nodes of cube : 26 , Elements of cube : 48 , Response: about $20-25 \mathrm{~Hz}$

\section{5. まとめ}

本プログラムにより, 臓器モデルと剛性物体の接触による変 形の程度を視覚的に確認するだけでなく忍力值を算出する など定量的に評価することが可能となった。

\section{6. 新文献}

1) G. Debunne, M. Desbrn and M. -P. Cani and A. H Barr: "Dynamic Real-Time Deformations using Space \& Time Adaptive Sampling", Proceedings of SIGGRAPH'01, August 2001. 